\title{
Collectivity and agency in remembering and reconciliation
}

\begin{abstract}
Summary
This paper examines how British war veterans fold together war time and post war experiences in practices of remembering and reconciliation. We examine these practices as networks of association between British ex-servicemen (veterans) and the people, places and circumstances associated with their experiences as prisoners in Japan during WW2. We focus on the experience of World War 2 British ex-servicemen (veterans) who were prisoners of war in Far East. During their period of captivity they worked to build Thai-Burma Railway before transfer to a copper mine in Japan. Some 50 years later they participated in a "reconciliation trip" to Japan. We discuss two related issues. First, how and in what ways are the post war lives and war time experiences of these veterans gathered up in the emergent collectivity of such practices? In other words in what ways do these practices emerge and sustain themselves as a process of collection and dispersion of circulating reference in networks of association between people places and things. Second, we examine how accounts of redemption (claims to the consequences of experience as being other than you would expect them to be) create the basis for emergent forms of agency and settlement in expanding networks of remembering and reconciliation.
\end{abstract}

\section{Introduction}

We examine in this paper practices of remembering and reconciliation in the context of the war and post war experience of British ex-serv- icemen (veterans) who were prisoners of war in Japan during WW2. We are interested in the interplay of the practices of remembering and reconciliation. We address the following questions. How and in what ways are the post war lives and war time experiences of these veterans gathered up in the emergent collectivity of such practices? How do these practices emerge and sustain themselves? In what ways is the agency of those involved reformulated in relation to the positioning and recontextualisation of war time experiences.

\section{Practices of remembering and reconciliation}

There are of course multiple ways in which to contextualise such war and post war experience - in the immediacy of social interaction; as part of institutional and cultural practices; within historical discourse. For example, in terms of the way people remember such experiences, we might contextualise the matter of 'memory' in history and examine how people draw upon some 'grand narrative' of events in the construction of their personal identities and biographies (e.g., Neisser, 1982, Brown, Shevell and Rips 1986). In other words, we can study how the patterning of history is taken as some 
global benchmark and context for an individual's memory and identity. Such work explores how autobiographical memory and identity is patterned in relation to significant events such as declarations of war, assassinations, centenaries, national commemorations and celebrations etc. (e.g., Conway, 1997). In contrast, we might localise experience within lived interaction and examine how the past, as both an individual and collective concern, is made relevant within the local pragmatics of communicative action. (e.g., Middleton and Edwards, 1990; Edwards and Potter, 1992; Billig, 1999). We can find the same oscillation between global and local contexts in practices of reconciliation. For example, in the work of truth commissions (Andrews, 2003) in determining what should or should not be included "in the story a nation tells itself about a traumatic past." (p. 45) contrasted with the role of commissions in the settlement or healing of personal trauma (Swartz and Drennan, 2000).

\section{Connecting the local and the global}

Is it possible then, to reconcile this oscillation between the local and the global, between on the one hand the immediacy of local interaction and personal settings of action, and on the other hand the more global context of historically anchored remembering? One way forward is to define a position where there is "no principal separation of what traditionally is viewed as individual or personal memory from what traditionally is viewed as social, collective, or historical memory," as suggested by Jens Brockmeier (2002a, p. 9). If we start from such a position we can focus empirical concern to examine what mediates between the local and the global. For example, as in Jim Wertsch's (2002) recent work on collective remembering as the study of the dialectical relationship between active agents and cultural tools.

\section{Mediating between the local and the global}

Wertsch (2002) describes remembering as an active process and distributed between persons. He locates the literal act of 'remembering' within the individual, but the significance and meaning of the activity is given by how individual acts of remembering are interdependent with one another. In remembering, the individual responds to, accommodates, modifies or even resists the memories of others. This responsiveness to others is entirely integral to the act of remembering itself. Although remembering is achieved by individuals, it is part of a distributed activity that is socially co-ordinated in every respect.

How then exactly are distributed acts of remembering bound to one another? Drawing on ideas from Bakhtin and others Wertsch's solution is to make semiotic mediation the focus of analysis. This refers to the range of 'cultural tools' which persons employ in accomplishing remembering activities. What counts as a tool is quite broad - language qualifies, as do narrative texts and technologies such as web based search engines. Since these tools are communally shared, co-ordination amongst users is in-built into their use. This shifts questions of the continuity and change of memory away from individual actors. For example, continuity does not necessarily indicate that the cognitive contents recalled by individuals are similar. It resides in the nature of the tools through which they collectively attempt to make sense of the past. Wertsch examines generational differences in collective remembering. He argues that the continuity in the accounts of the past produced by the generation who grew up in post second world war Soviet Russia can be directly indexed to a massive state control of history education in terms of curriculum content and time-tabling. Control over mediational resources was a means of ensuring that what can be collectively remembered is 
shaped to fit official, state-sponsored versions of the past. In addition, mediational tools also exist in given contexts. These contexts are never neutral, they are sites where collective remembering as a practice rubs up against the state production of 'official history'. In Soviet Russia this confrontation was often marked by an all-pervading sense of distrust of the narratives and resources provided by the state. This cynicism with regard to official narratives reflects what Wertsch terms a more general 'tension' between individuals and the mediational tools which resource human activity. Wertsch argues we might master a narrative but we do not necessarily appropriate it.

Wertsch uses this tension as a way of describing how narratives may be consumed without invoking a problematic vocabulary of 'internalisation'. He proposes a dialectical relationship between the individual, endowed with sets of beliefs and values, and the state control over the contexts and resources through which these beliefs might be shaped and expressed. However we might examine in more detail how the informal and formal infrastructure interact with the activity of remembering. For example, the widespread sense amongst Soviet citizens that counter-narratives could not be publicly voiced was founded on the operation of a massive system of monitoring, recording, reporting and archiving information on individuals which was formalised through a party administrative apparatus. This colossal system of surveillance established a distributed set of contexts in which remembering might be conducted.

What infrastructure might be required to produce state-sponsored versions of history though the co-ordination of class times across all time zones? Presumably something like a workable system of telecommunications, the hooking up of local education administration with central centres, the movement of books, materials and teachers and so on. Now these seemingly mundane details are important be- cause if collective remembering is shaped by the contexts in which it occurs, then we not only need to grasp the contours of these contexts, we need to understand the ways in which contexts are linked and communicate with one another. In other words we need to focus on how such contexts are built and connected.

We share the concerns of both Jens Brockmeier and Jim Wertsch to explore the dynamic of collective remembering without attendant dualisms where "(I) $t$ is neither individual nor collective, local nor global, an interiority or exteriority, but a dynamic process of movement that combines and associates the self and the other, the now and the then, the here and the there" (Brockmeier, 2000b, p. 21). Brockmeier points out that we therefore position "mind as one element in this movement; which is to realize that a decontextualized mind, a mind taken out of its discursive and cultural environment, is an abstraction that isolates just one moment in a continuous flow (Brockmeier, 2002b, p. 21/22). However there is a sense in which this presumes, or takes as given, the contexts within which minds are contextualised. We need to enquire into how such contexts are produced as both local and global concerns (cf Latour, 1999) ${ }^{1}$. Bruno Latour (1999) argues that in order to do this we need to move away from the analysis indexed to scale (local/global) and focus instead on the circulation and displacement of objects. In other words we examine what makes remembering possible, not what expresses what already exists either as some internal process or externally located expression or inscription of the past. Agency and collectivity become analysable as emergent effects generated by networks of interacting and interconnecting materials. What counts as memory, reconciliation, an identity as POW or civilian, emerges in the way sets of elements come together and then stretch out over and

1 See also discussions of the Pearl Harbour 50 ${ }^{\text {th }}$ Anniversary by Geoffrey White, 1997. 
heterogeneous networks of people, things and places. This is the concern of this paper. Our concern is with the mediational action that extends and folds the local and the global into each other. We wish to examine how the local and the global intersect in ways that continually reconfigures the matter (as topic and substance) of remembering and reconciliation.

\section{Towards remembering and reconciliation as networks of association}

As we have already indicated we draw in part on a view of networks outlined in the work of Bruno Latour and his colleagues (see for example, Law, 1992). Marilyn Strathern (1996) notes that '[actor] network imagery offers a vision of social analysis that will treat social and technological items alike; any entity or material can qualify for attention' (p.526). The concept of actor-networks made up of a tracery of heterogeneous elements (human and non-human, culture and nature, technology and society) challenges reductive approaches to social and psychological analysis ${ }^{2}$. Social structure is not treated as some bedrock of roles, norms, rules and procedures that determine or effect the order and diversity of human behaviour, but as an emergent effect of ongoing processes of ordering. Such analysis contrasts with the idea that the 'social' holds us together. It proposes instead that by virtue of the mediation of non-humans and materials that sociality is formed:

'If human beings form a social network it is not because they interact with other human beings, it is because they interact with human beings and endless other materials too' (Law op cit, p. 2).

2 See Callon 1986 for a classic demonstration of emergent alliances formed between human and non-human entities.
Networks are hybrids whose critical force, as Strathern (1996) argues, challenges the notion of pure form which separates out for analytical convenience "technology and society, culture from nature and human from non human". (p.520). One of the key analytic moves in actor-network analysis is to examine translations, inscriptions and points of passage in the flow and topology of heterogeneous networks. We argue that the remembering and reconciliation might usefully be approached from just such an analytical perspective.

\section{Overview}

We introduce our arguments in a discussion of a commemorative gravesite in Japan that became a point of passage in the veterans participation in their post war "reconciliation visit" to Japan. Emergent collectivity in both the practices of remembering and reconciliation are made visible in the ways in which the site becomes attached to people and practices. In so doing the site is put into circulation in a whole range of resources (books, pictures, interviews etc). The memorial site is transformed and translated into a form of "functional blankness" (Hetherington, 1997) or "blank figure" (Hetherington and Lee, 2000); detached from any particular location and dispersed into multiple networks of remembering and reconciliation. It becomes both subject and object in the collection and dispersion of circulating reference (Latour 1999). We argue for a view of the practices of remembering and reconciliation as heterogeneous network of elements (human, material inscriptions and points of passage etc.). We then focus on the emergence of agency in networks of translation. We do this by examining how accounting for redemption ("redemption narratives") summate and condense the cascading networks of the form and matter of remembering and reconciliation. These narrative accounts fold together disparate features of war and postwar experience. They are a hybrid form in the 
way they simultaneously condense the matter of person in terms of position, place, ethnicity, whilst also making available evaluation, feeling and new forms of belonging (cf., Strathern, 1996). Such accounting for redemption calls into question any pre-established consequences of war time experience for current and future action. We are therefore interested in how their hybrid organisation cuts and collects up the contingencies and consequences of war and post war life and in so doing repositions agency as emergent in the ambiguities potential in the veterans' lives - of being other than one might expect oneself to be.

\section{Setting for the study of reconciliation and remembering}

Focusing on material concerning the post war consequences of being a prisoner of war, we draw on an example from a corpus of interviews with World War 2 British veterans who were prisoners of war in Far East (Murakami, 2001) and other materials (pictures, books, memorial sites) associated with their post war lives. During their period of captivity the interviewees worked to build Thai-Burma Railway before transfer to a copper mine in Japan. Some 50 years later in 1992 former British POW's returned to a memorial site in the vicinity of the mine. This visit was part of a whole series of events that were organised as a result of the grass root rather than state initiated efforts of both Japanese nationals living in the UK, veterans associations and people in the locality of the memorial to promote reconciliation. The memorial site and the circumstances of its creation and maintenance became the focus of effort to organise the reconciliation visit for the surviving POW's.

Their participation in the work reported here is part of the continuing emergence of collectivities (networks) of people and material organised in terms of issues of remembering and reconciliation. For example, the conduct of interviews by a Japanese national in the domestic environment of the 11 respondents made this study one further point of passage through which the flow of people and material (reminiscences, souvenirs, diaries, camp artifacts) are brought together. The mores of social conduct in entertaining and offering hospitality to someone whose ethnicity directly associate her with their war and post war experiences contextualise and configure the ways in which such experiences are made relevant and accounted for. Such collection or bringing together of camp and domestic life, of war time and post war dealings with Japanese people (as in the interview for this particular study), both collects and makes available for dispersion the contingencies, contrasts and consequences of war and post war experience.

\section{Emergent collectivity in networks of reconciliation and remembering - Circulating reference}

The commemorative site in the picture below is situated in the locality where 300 British prisoners of war laboured in a copper mine from 1944 until the end of the war in $\mathrm{Au}$ gust 1945. However, the site pictured in this photograph is not the original location of the memorial. The current memorial site was created by local Japanese people. It results from a transformation of a small grave site memorial initially erected by the British POWs for their colleagues who did not survive the war. We enquired into the history of the site's relocation and transformation to learn how the current memorial emerged from a local initiative. We also identified how it was 'discovered' and appropriated into a wider range of commemorative and conciliatory activities. Its circulation is a key to understanding the dynamic of 


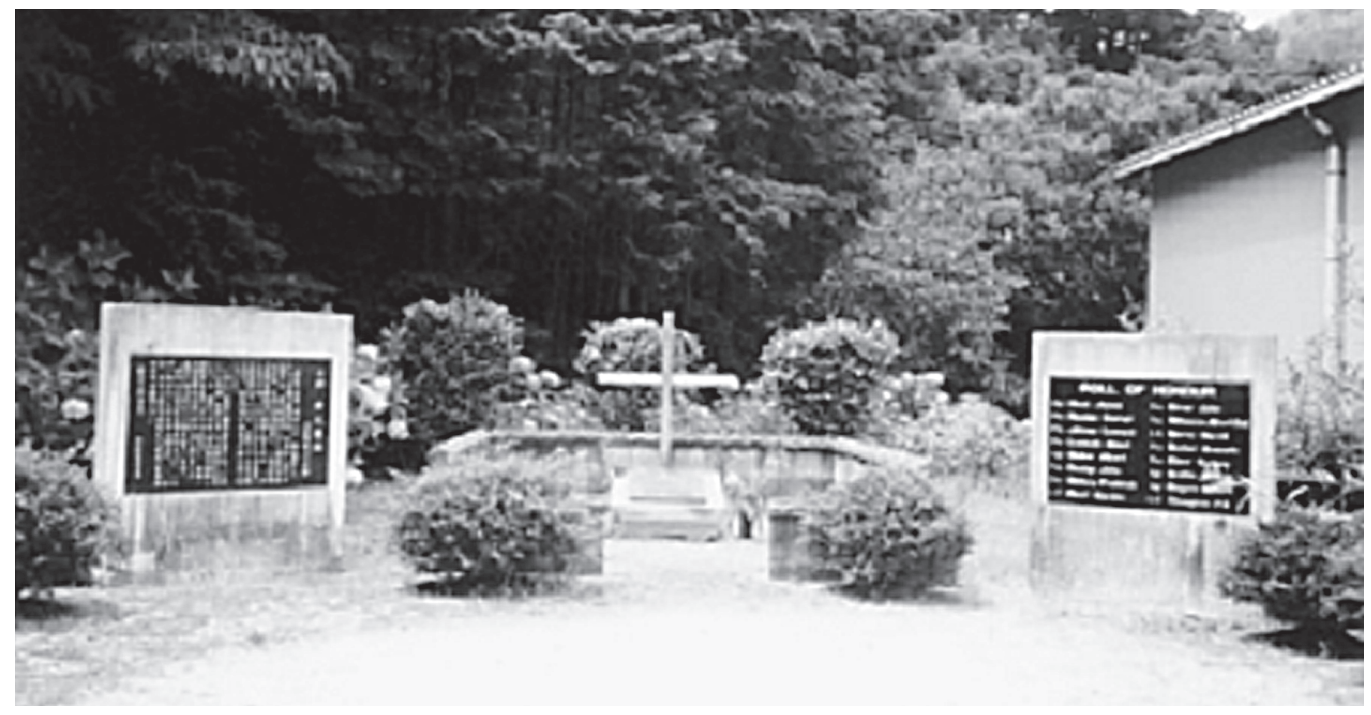

Photo: Kyoko Murakami

remembering and reconciliation as emergent collective phenomena. This dynamic is one of circulating reference (Latour 1999).

By circulating reference we mean that the memorial is inscribed in stories of discovery, mobilised in reconciliation activities and civic and international ceremonial, and incorporated into research on the dynamic of collective remembering. Its substance is continually transformed and extended into the network of circulating reference. For example, it was initially a small grave with a wooden cross and a commemorative plaque recording 16 soldiers who had lost their lives. This site was built by the surviving British POWs before they left for Britain in 1945. After the war, the site, known as gaijin-bochi (tr. a grave for foreigners) continued to be maintained as part of the activities of a senior citizen's group. The group provided voluntary routine care of the grave including weeding and the maintenance of floral tributes. In 1990, former student workers, who worked with British POWs in the mine, held a memorial (in Japanese, Ireisai) as part of their High School reunion. This was to commemorate the relocation and refurbishment of the grave and memorial to a new site some hundred metres away. The whole memorial was redesigned and refurbished with the replacement of a new copper cross and stone memorial plaques to the left and right of the cross. To the right the grave was a replica of the original Roll of Honour of the names of those soldiers who had died was reinstated (see photograph). Also of significance, to the left of the Cross, was installed a further plaque entitled Gaijin-bochi inscribed in Japanese giving a brief history of the grave, marking the war-time presence of the British soldiers who worked at the copper mine. These soldiers became known amongst themselves, and to others, as the "Iruka Boys".

This grave was virtually unknown to the outside community, let alone to the British until two people who had associations with Britain came to 'discover' it. Taken by his colleague, Fr Murphy, a Catholic priest visited the grave. He wrote an article about this visit for a religious newspaper which is reprinted in $A$ Little Britain (Former FEPOWs and Homes 1991). The following is an extract detailing his visit and the history of the grave:

Recently, when visiting [my colleague] in his parish ... some 350 miles south-west of Tokyo, I had an 
experience which I found touching. At the outskirts of the village [my colleague] stopped the car and there, in front of my eyes, was a Memorial to sixteen British soldiers who had died, just before the end of the World War II, at a prisoners camp here. Two things immediately came to my attention; one was the Roll of Honour with the soldiers' names displayed in bold print; the other was the fresh flowers that had been placed in the receptacles on either side of the monument ... To the left of the monument was an explanation of why the Memorial was in this place. It read: "Burial ground for Foreigners. On the $18^{\text {th }}$ June 1944, 300 prisoners of war were transferred from Malay by the Japanese army, and under the direction of the army a P.O.W. camp was erected near the present site. More than half of the prisoners were put to work in a nearby ore mine. The rest worked in the ore processing plant or on land relocation. These men being English, were cultured and had a high sense of pride. Their work was efficient and they themselves were gentlemanly. Moreover, some had contracted sickness before the end of the war, 16 died. The surviving 284 returned to their own country." One the copper plaque the following words are inscribed: "To the greater glory of God and in memory of men of the British Forces who died at or near Itaya during the war of 1941 - 1945." (Murphy, 1991; p. 13)

This article was brought to an attention of one of the "Iruka Boys", who immediately wrote back to the catholic priest, and they began corresponding. Meanwhile, Keiko Holmes, who was originally from this community, now residing in the UK, learned on one of her home-coming visits that the grave was refurbished. A copy of the correspondence between the catholic priest and the Iruka veteran was sent to her mother, who worked as a community centre worker in the locality of the memorial site, and then to Keiko Holmes in London. Keiko Holmes established contact with the surviving Iruka veterans visiting them in various parts of England.

The visits led to the publication of $A$ Little Britain (Former FEPOW \& Holmes, 1991), noting the special significance of a memorial that was maintained by the former adversaries of those commemorated. This is a collection of memoirs of the Iruka camp, correspondence between Japanese and British people about the discovery of the grave and accounts recorded by Keiko Holmes after visiting some of the Iruka Boys. She was the key figure in contacting surviving "Iruka Boys" and organising the first reconciliation visit to Japan in 1992 and in sustaining further such activities ${ }^{3}$. In summary, it was through these contacts that the post war veneration and significance of the site to the local Japanese population came to the attention of Iruka veterans back in the UK.

The site, therefore, became a point of passage, not just as a place to visit but as a node in a whole network of heterogeneous relations and transformations. For example, surviving "Iruka Boys" and their family members, accompanied by Japanese nationals residing in the UK, went to Japan for a joint-memorial service to commemorate the dead POWs (Former FEPOWs and Holmes 1991). Before and during the trip, there was a significant amount of publicity in Japan about this visit. The general public made monetary contributions and wrote letters of support to the reconciliation trip committees. One of the former POWs had already written a personal memoir of the camp life in Burma and Japan. The memoir was written initially as a recollection of camp life, but was enlarged to include a chapter detailing reconciliation visits of 1992 and 1994. This was later published as a book (Walker 1997).

The site continued to be transformed in the networks of association concerning remembering and reconciliation. For example, it was further embellished shortly after the first reconciliation trip in October 1992, to mark the original "Iruka Boys" return to Japan with the placing of another stone plaque by the local

3 See the URL of Agape (http://www.agape-reconciliation.org/) an organisation set up by Keiko Holmes to promote Anglo-Japanese reconcilation. 
Committee of "Iruka Boys Pilgrimage". Formally known as burial ground for foreigners it was a key site associated with Anglo-Japanese reconciliation, to which groups of the other British veterans and family members were taken as part of "pilgrimages" organised by Keiko Holmes.

The history of this grave and its multiple positions in the dynamic process of remembering and reconciliation illustrates Latour's (1999) notion of circulating reference. He points out that it is a mistake to treat phenomena (e.g., remembering) as "the meeting point between things in themselves and categories of human understanding. (...) Phenomena are what circulates all along the reversible chain of transformation" (Latour, 1999, p. 71). The gravesite circulates in a whole variety of transformations or translations. It is transformed in the social practices and mediated actions of organising and taking part in reconciliation trips, doing research on the experience of reconciliation, and talking about the memorial service and the veterans war-time experience, etc. It is translated into textual resources of discursive remembrance (e.g., reunion and reminiscence, visual images, newspaper articles, personal memories and letters, and web site materials). The collectivity of remembering and reconciliation is an emergent effect of materials and humans held together in the circulating reference of the memorial grave site. Even the grave site literally moved in one of the transformations that formed part of the network of reconciliation and remembering. Furthermore, it became incorporated as part of the heritage of the area in local government's projects working toward regeneration and development of what was formerly a place with a long standing reputation as a mining centre.

However, in claiming that the site is both collected and dispersed in the dynamic of circulating reference, just what sort of subject or object is it? What is the Iruka memorial gravesite? It is not just an assemblage of objects at a particular site - too important for that. Rather it is an object defined by the kinds of passages it undergoes and the effects it produces in the subjects and objects that surround it. Perhaps a kind of subject then in itself? Not quite, because it is something that makes the adoption of subjectivity of the veterans and the other participants possible. It is the means by which their subjectivity is marked out. In other words, it is the medium against which fragile relations of reconciliation are cast and whose very presupposition of significance makes them possible. It is beyond settlement as either subject or object; it is both. It is a kind of third party, a space beyond any immediate context of communication - a common medium to which all parties can appeal. It is both the object (the entity that circulates and is dispersed), and the subject (the recipient of attention) as the point of passage that collects together the heterogeneity of reconciliation and remembering.

\section{Collection and dispersion}

In this sense the grave site is a indeterminate 'object', with which the dynamic of reconciliation and collective remembering is empirically observed and held together. The point being that it too is subject to continual positioning as both a local and the global concern. It is can be positioned in all sort of multiple ways - as a local place perhaps, a forgotten a place of burial for fallen comrades; as a local place that translates enmity into respect but remembered; as extended into the networks into the distal concerns of families and friends; as centre of co-ordination for reconciliation. It is a centre/ node through which the flow passes but it is also what circulates and is dispersed in the network to continue the process of gathering up and dispersal (cf., Cooper, 2001). The more the grave site is gathered or collected into the practices of remembering and reconciliation the more the site disperses and the more ambiguous it becomes. It not only becomes something 
different according to how it is placed, but it also generates effects on the collective which surrounds it and opens up possibilities for how that collective may relate to itself. In this sense it is both a "marker of social relations" and the medium or $3^{\text {rd }}$ party which makes them possible, which holds them together. And it does this precisely by being endowed with a form of indeterminism or ambiguity. The grave site becomes an indeterminate object that weaves the emergent collectivity of remembering and reconciliation. This does not mean that the grave inherently has these functions. Kevin Hetherington (1997) calls this kind of indeterminism "functional blankness". In an analysis of the dilemmas surrounding the incorporation of a material artefact (a piece of pottery called "Ozzie the Owl") in a museum display, Hetherington argues that this blankness is highly potent since it calls into question the forms of ordering into which it is subsumed and allows them to be reformulated. As the site circulates in a chain of transformation it appropriates further relations transforming and reordering the relation between past and present, generations, localities (England, Burma, and Japan). Each transformation opens up new trajectories and re-collections. Collectivity as an emergent effect is made visible in the forms of reconciliation activities which were the focus of our research.

\section{Cutting the net: enumeration and emergent agency in reconciliation}

However there is a potential problem with such a view. What form of logic governs its extension and provides the network with resources to halt its seemingly inexorable advance? This problem directly flows from the analytic position that mixes up humans and things. Marilyn Strathern (1996) spells this out in more elegant terms:
The power of such analytical networks, is also their problem: theoretically, they can be without limit. If diverse elements make up their description, they seem as extensible or involuted as the analysis is extensible or involuted. (...) Yet analysis, like interpretation, must have a point, it must be enacted as a stopping place. (p. 523)

For Strathern, the operation of making visible heterogeneous relations between people and things brings with it a "fractal logic" where more elements may continuously be revealed - "one can always discover networks within networks" (p. 523). Drawing on anthropological studies of Melanesian kinship relations, Strathern argues that what is lacking from such analysis is some principle wherein the network might be "summed up" or "enumerated" in such a way that it can be seen to come to a stop, however provisional - "in coming to rest, the network would be "cut" at a point, "stopped" from further extension" (p. 523). For Melanesians, this kind of summing up is done when the properties and obligations, that is the networks of relations, of a deceased ancestor are transferred into "shell money" during funeral rights. How to locate such a principle in Euro-American networks? Strathern notes that the image of a "hybrid" - generally taken as the metaphor which expresses the mixture of heteregenous elements in the work of both Latour (1992) and others such as Donna Haraway (1991; 1997) - is itself a kind of summation, a gathering together in a stopping point. She offers the example of patent rights to laboratory derived cell lines where ownership is granted by successfully demonstrating the mixing up of technology (i.e. laboratory technique) with culture (i.e. scientific expertise) and nature (i.e. the original tissue material). In other words, for Euro-Americans, the demonstration of hybridity in an object or phenomenon comes to act as a stop on the potentially limitless expansion of the network.

We can see the need for some sort of enumerative dynamic in relation to Gaijin- 
bochi, the memorial. More things are continually being added. But in what sense can it be claimed that reconciliation is accomplished in these networks of translation of the site? The graves site also circulates and recruits. However, in what ways does it sum things up or make available some form of settlement? Does the continual attachment to it provide for some alignment of interests between the ex-POW's and their Japanese hosts/guards and guest/interviewer? There appears to be no point of settlement. Can we find some resources that accomplish such a settlement, no matter how temporary, in the flow of veterans post war lives? In the interviews with these veterans they produced accounts that were configured in ways that demonstrated the form of hybridity discussed by Strathern (1996). These accounts made visible the issue of redemption as a concern for participants in the interviews. Such accounts report, display and evaluate the consequences of actions as being otherwise to what might be warranted from war time events and experience and reported feelings of post war animosity toward Japanese people. They constitute a hybrid form that comprises connections with persons, social practices, materials and evaluations.

\section{Accounting for redemption}

We argue that these redemption accounts provide a way of accomplishing a summation or enumeration in the network of reconciliation and remembering. We illustrate this point with reference to the following interview extract. This interview was conducted in the home of one of the Iruka veterans. Also present were his wife, another veteran, and another Japanese person associated with the Iruka visits who had assisted in arranging contact between the interviewer and the veterans.

This interview is part of the flow of reconciliation practices where reconciliation matters for those who took part in the interview.
The interviewees were requested to reflect and illustrate the consequences for them of participating in the return visit to Japan in 1992. This particular account was produced after the speaker shared with the rest of the participants an episode of a "little reunion" with his "old mates" at Heathrow airport on the day of their departure for Japan on the reconciliation trip. He said "that this reunion put him on the road to reconciliation" after having experienced the camaraderie of seeing them at the airport. This account is a point of summation in all the multiple reminiscences these veterans produced not only about the post war visit to Japan but also about their life as a prisoner of war.

The account has the features of what Brockmeier (2002b, p. 33) calls a linguistic order of narrative (e.g., linguistic order such as the scene, agent, intentionality, goals, solution, predicament). However, the account displays participants' concern and is developed interactionally. If we consider the sequential organisation of this interview, we can identify the moment of settlement and dispersion in the interaction itself in the way in which the relation between the speaker and the hearers (i.e., present others) are interactionally making sense of the account. This sense-making is a kind of a settlement, in terms of establishing a shared sense of the past and the significance and the upshot of the current interaction. We can see that there is a symmetry of action between the speaker's photo-taking experiences in two different occasions-before and after the reconciliation trip. This story invokes a notion of change and presents a basis for evaluating that change. It summates the way in which the speaker, Fred, has changed due to the participation in the trip. The story marks the speaker's change toward the Japanese and a new perspective that Fred now possesses. This is presented by the speaker himself as a possible redemption, "I thought perhaps I've been redeemed at last", even though "You know that's a little thing". The first "story" does not 
Interview Extract (conducted in 1999)

F: ex-POW, M: Japanese contact, Int.: Interviewer (Kyoko Murakami)

1. F: I was in Battersea Park some years ago,

2. after the war, ten years after the war and

3. I'm sitting out in the open air with a cup of tea

4. at the table and two little children running around

5. in front of me and I said to myself,

6. "oh my god, is that Japanese". Because they could be

7. Chinese or Thai,

8. Int: hum

9. F: you know what I mean, but to me they were Japanese I thought.

10. I didn't have to wonder very long, because just behind me

11. (there's) somebody calling out "Oi, koi." Right? "come here"

$12 . \quad$ or

13. Int: hum

14. F: yes?, I thought I know that. That means 'come here',

15. or means 'come back'. I half reluctantly turned around and

16. (at) the next table behind me was a Japanese man and woman.

17. They all got up and they went down, stood by the lake.

18. And this is the story. He took a picture of his wife and

19. two children. She came and took a picture of him and the

20. two children. And me being, I don't use the camera

21. and all that, but what I would normally do in a case

22. like that, and I have done it many times (.) I would go out

23. and say and "Excuse me, do you mind if, would

24. you like me to take a photograph of all of you?"

25. Int: Yes

26. F: I half got up and I thought "No why should I. "

27. And I regretted that. I regretted it. But some years later,

28. when I was over at Keiko's place in Croydon,

29. a Japanese man, lady, doctor?

30. M.: Hiro?

31. F: and the two children they came and they stood on the

32. stairs by Keiko's room there and I took a photograph

$33 . \quad$ with my camera then.

34. I thought perhaps I've been redeemed at last. (ha ha ha)

$35 . \quad$ You know that's a little thing.

36. Int: Yes. 
stand alone. Immediately, the speaker produces the second "story" as a way of establishing his entitlement to being a changed person. Sacks (1992) argues that in order to demonstrate an entitlement to an experience claim involves presenting an equivalent but different experience in any second "story". There is a sense then in the discursive organisation of these accounts of the ways in which local (e.g., subjective dispositions) and more global issues (e.g., collective identities - Japanese) are made to intersect.

\section{Emergent agency in summation and ennumeration}

The way this accounting is accomplished precisely illustrates a summation or enumeration (cf Strathern, 1996). In this sense it is a hybrid object because it simultaneously condenses the matter of person in terms of position, place, ethnicity and of evaluation and feeling. The second story is both within and beyond the re-contextualisation of the events described. It varies the scale and extension of the events, extending them into the network of relations with people and material.

The camera is more than or rather does not stand alone as an object used by the agent to record and display his position, it mediates but also extends the agent. This camera attachment (sic) is the basis on which the actions are evaluated as in the initial story it was the camera detachment (the resistance to act). There is more than some irreducible tension between active agent and cultural tool, where the camera brings into, or extends into the setting of all those practices that are the cultural norm for the ways in which we might offer mutual assistance in the public execution of picture taking. The move between detachment and attachment within the compound of the account (declining or taking up the position of assistant photographer) extends the agency of the person giving the account and the con- textual range of such actions both within the events narrated and for possible engagement in future. It is the in move between detachment and attachment, of not taking up a position of assisting in picture taking and taking up the position of picture taking, that a new form of agency emerges. The move between the first and second story or position within the account in terms of ethnicity, place and attachment/detachment both encloses and extends an emergent form of agency.

This accounting therefore gathers up and ties together heterogeneity both in terms of people, material, places, time, practices etc. and evaluative significance. It enumerates but in ways that makes such summation available for use by others and by the those who are part of such accounting - a form of collection and dispersion. Such hybridity provides the basis for interrupting and reflecting ordered relations in experience back on themselves. Its potency is that it provides the basis for calling into question the ordering of lived experience into which they are subsumed and allow it to be reformulated. It "contains" the difference that makes the difference. This is precisely what we mean by emergent agency, for what is it that allows for the attribution of agency? It is the sense that something or someone is not following some pre-established programme of action - is not expressing some pre-existing structure. Agency is a kind of ambiguity, a break with what we expect. The exercise of agency is a break, a rendering of oneself as otherwise to what was previously understood to be the case. The enumeration or summation that makes the difference. A form of settlement that extends beyond itself.

\section{Conclusion}

Our concern is therefore with unfinished business, unfinished business consequent upon having lived through and experienced the privations of war time incarceration and forced 
labour as prisoners of war. Such experiences and events remain live concerns both for first hand participants, in their relations with others, in the patterning of their lives and in the ways in which they participate in the flow of the multiple networks of association, of which their finite and commemorable lives are a part. We do not treat the dynamic of reconciliation as one of settlement and conversion of experience into some form of finished product (Williams, 1977). For as Holland, Lachicotte, Skinner \& Cain (2001), point out identities are live concerns, "they are being lived - are unfinished business and in process" (p. vii). To project endings would be to convert "relationships, institutions and formations in which we are still actively involved ... into formed wholes rather than forming and formative processes" (Holland et al, p. vii, quoting Williams, 1977). That is what we seek to do in our consideration of remembering and reconciliation. We aim to present a view of reconciliation and remembering as unfinished business and necessarily so. In so doing we take both subjectivity and collectivity as unfinished, as emergent effects within a dynamic of collection and dispersion of circulating reference.

We have introduced these arguments through a consideration of both the post war experience of veterans and their post war contact with Japan. We presented how the collectivity in reconciliation practices emerges in the collection and dispersion of circulating reference within heterogeneous networks (conversations, material inscriptions and points of passage etc.). However such a view raises questions concerning whether such networks of association are ever cut in ways that afford some form of reconfiguration or break in the expected consequences of war time experience. In other words for a form of settlement no matter how temporary to be accomplished. We argued that the way veterans produce accounts of the post war consequences of their war-time experiences organised in terms of accounts of redemption ("redemption narratives") provides one such resource. In other words reporting and displaying the consequences of actions as being otherwise to what might be warranted from war time events and experience. Such accounting gathers up and ties together heterogeneity both in terms of material (people, places, time, practices etc.) and evaluative significance. They are a hybrid form in the way they simultaneously condense the matter of person in terms of position, place, ethnicity whilst also making available evaluation, feeling and new forms of belonging. This is what makes them newsworthy and tellable. In their telling they fold together, collect up and contrast positions (as combatant, prisoner, civilian, parent, husband, bystander etc.), features of events (fellow prisoners, guards, social mores, camp practices; language, ethnicity), images and material circumstance (survival, food, working environments, post war life) and evaluations (personal and moral, assessment of self and others, ethics, ordinariness).

Agency as an emergent effect is demonstrated as break or summation that renders someone or indeed something otherwise to what might be expected. The potency of such (hybrid) forms of accounting is that that it provides the basis for interrupting and reflecting ordered relations in experience back on themselves and allow it to be reformulated. In tying together person and circumstance, past and present, materiality and morality, the future is dealt with an in interesting way. This is not a future built out of the past and the consequences this has for the way it determines the veterans' dispositions towards the Japanese. Rather, this is a future built back into the past such that there emerges the possibility of things being otherwise. In other words history matters in reconciliation and remembering not so much in terms of what happened in the past but in terms of how futures are built back into the past in ways that make for the possibility of things being different. 
Overall then this brings us back to the initial concern of this paper. Rather than asking how the local and the global connect, with some presumption that this might imply different and distinguishable levels of discourse and action, we see that such a distinction is rendered irrelevant. We do not need to assume that there is some distinction of scale to be bridged. Both collectivity and agency in remembering and reconciliation are demonstrated as emergent effects generated in the circulation and displacement of material - the mediational action of networks of people, things and places. It is not so much that we should look to explain how the local and global connect but rather we should ask how the local and global are continually constituted in the dynamic of circulating reference within such heterogeneous networks of remembering and reconciliation.

\section{References}

Andrews, M. (2003). Grand national narratives and the project of truth commissions: a comparative analysis. Media, Culture \& Society, Vol. 25: 45-65.

Atkinson, J.M. \& Heritage, J. (1984). Structures of social action: Studies in Conversation Analysis. Cambridge: Cambridge University Press.

Billig, M. (1999) Freudian repression: conversation creating the unconscious. Cambridge: Cambridge University Press.

Brockmeier, J. (2002a). Introduction: Searching for cultural memory. Special Issue on Narrative and Cultural Memory. Culture and Psychology, Vol 8(1): 5-14

Brockmeier, J. (2000b). Remembering and forgetting: Narrative as cultural memory. Culture and Psychology, Vol 8(1): 15-43

Brown, N., Shevell, S., and Rips, L. J. (1986). Public Memories and Their Personal Context. In David C. Rubin, ed. Autobiographical Memory. Pp. 137-158. Cambridge: Cambridge University Press.
Callon, M. and Law, J. (1995). Agency and the hybrid collectif. The South Atlantic Quarterly 94, 2, 481-507

Conway, M.A. (1997). The inventing of experience: memory and identity. In James W. Pennebaker, Dario Paez and Bernard Rimé (Eds.) Collective Memory and Political Events: Social Psychological Perspectives. Mahwah, N.J: Lawrence Erlbaum Associates

Cooper, G. (2001). Interpreting mass: collection and dispersion, in Rolland Munro (Ed.) Consumption of Mass. Oxford: Blackwell Publishers

Edwards, D., \& Potter, J. (1992). Discursive psychology. London: Sage

Former FEPOWs \& Holmes, K. (1991). Little Britain. Mimeo

Haraway, D. (1991). Simians, cyborgs and women: The reinvention of nature. London: Free Association Books

Haraway, D. (1997). Modest_Witness@Second_ Millenium.FemaleMan (C_Meets_OncoMouse $^{\mathrm{TM}}$. London: Routledge

Hetherington, K. (1997). Museum topology and the will to connect. Journal of material Culture, 2(2): 199-220

Hetherington, K. and Lee, N. (2000). Social order and the blank figure. Environment and Planning D: Society and Space. Vol. 18: 169-184

Holland, D., Lachicotte Jr. W., Skinner, D. \& Cain, C. (1998). Identity and agency in cultural worlds. Cambridge, Mass: Harvard University Press

Latour, B. (1992). Where are the missing masses? In W.E; Bijker and J.Law (Eds.) Shaping technology/building society. Cambridge, Mass: The MIT Press

Latour, B. (1999). Pandora's Hope: Essays on the reality of Science Studies. Cambridge, Mass: Harvard University Press

Law, J. (1992). Notes on theory of actor-networks. Systems Practice, 5(4), 379-393

Middleton, D. and D. Edwards, Eds. (1990). Collective remembering. Inquiries in social construction. London: Sage

Murakami, K. (2001). Revisiting the past: Social organisation of remembering and reconciliation. Loughborough University: $\mathrm{PhD}$ Thesis 
Murhpy, C. (1989). In Japan a place that is forever England. In Former FEPOW's \& Keiko Holmes (1991) Little Britain, Mimeo, p. 13

Neisser, U. (1982). Memory observed: Remembering in natural contexts. San Francisco: W.H.Freeman and Company

Sacks, H. (1992a). April 24: Second stories. In G. Jefferson (Ed.), Lectures on conversation (edited by Gail Jefferson; introduction by Emanuel A Schegloff) (pp. 764-772 (Part VII)). Oxford: Blackwell

Strathern, M (1996). Cutting the network. Journal of the Royal Anthropological Institute, NS., 2, 517-535

Swartz, L. and G. Drennan (2000). The cultural construction of healing in the Truth and Reconciliation Commission: implications for mental health practice. Ethnicity \& Health, 5 (3/4), 205-213

Walker (1997). Of rice and men: the only true war story with a happy ending Stockport, UK, Arthur Lane Books

Wertsch, J.V. (2002). Voices of Collective Remembering. Cambridge: Cambridge University Press

White, G.M. (1997). Mythic history and national memory: The Pearl Harbour Anniversary. Culture and Psychology, Vol 3(1): 63-88

Williams, R. (1977). Marxism and literature. Oxford: Oxford University Press

\section{Appendix: \\ Transcription notation}

The transcript convention are adapted from those used by Gail Jefferson for the purpose of conversation analysis (see Atkinson \& Heritage, 1984).
Underlining
signals vocal emphasis
((text))
Additional comments by the transcriber, e.g. gesture, con- text or intonation comments
(.) micro pause
${ }^{\circ}$ well $^{\circ} \quad$ softer utterance
yeh,

has not finished; marked by fallrise or weak rising intonation, as when enunciating lists.

y'know? Question marks signal stronger, 'questioning' intonation, irrespective of grammar

yeh. Periods (full stops) mark falling, stopping intonation ('final contour'), irrespective of grammar, and not necessarily followed by a pause

bu- but Hyphens mark a cut-off of the preceding sound

ha ha Voiced laughter

um Fillers between words.

Oi koi Italicised words are of Japanese origin.

\section{Acknowledgements}

We are grateful for the opportunity to present this paper to the Faculty of Humanities Lecture Series at the University of Copenhagen on the $28^{\text {th }}$ March 2003. Other versions were also presented at the Fifth Congress of the International Society of Cultural Research and Activity Theory, Vrije Universiteit Amsterdam, The Netherlands, 18-22 June 2002 and at The Society for Psychological Anthropology Biennial Meetings Catamaran Hotel, San Diego, CA. April 10-13, 2003. Comments on this work from Steve Brown, Ole Dreier and Morten Nissen are gratefully acknowledged. We sincerely thank all the participants for taking part in the interviews. This research was partially funded by a UK Government Overseas Research Scholarship held at Loughborough University, UK. 